\title{
Peritoneal lavage with coconut water in rats with abdominal sepsis and its effects in peritoneum
}

\section{Lavagem Peritoneal com Água de Coco em Ratos com Sepse Abdominal e seus Efeitos no Peritônio}

\author{
Kartagena Martins Barreto Borges ${ }^{1}$, Ítalo Medeiros Azevedo ${ }^{2}$, Lívia Medeiros Soares \\ Celani $^{3}$, Aldo Cunha Medeiros ${ }^{4}$
}

1. Graduate student, Medical School, Federal University of Rio Grande do Norte (UFRN), Natal-RN, Brazil.

2. Fellow PhD degree, Postgraduate Program in Health Sciences, Federal University of Rio Grande do Norte (UFRN), Natal-RN, Brazil.

3. MD, University Hospital Onofre Lopes, UFRN, Natal-RN, Brazil.

4. Full Professor, Chairman, Nucleus of Experimental Surgery, UFRN, Natal-RN, Brazil. CNPq/PQ.2 fellowship.

Study performed at Department of Surgery, Federal University of Rio Grande do Norte (UFRN), Brazil.

Financial support: none.

Conflict of interest: None.

Correspondence address: Department of Surgery, Federal University of Rio Grande do Norte, at Ave. Nilo Peçanha 620, Natal, RN, Brazil, E-mail: cirurgex.ufrn@gmail.com

Submitted: June 02, 2017. Accepted, after review: July 05, 2017.

\section{ABSTRACT}

Purpose: This study aims to analyze the effects of peritoneal lavage with coconut water on the peritoneal reaction in abdominal sepsis model in rats. Methods: We used 12 male Wistar rats weighing between $310 \pm 15 \mathrm{~g}$. The animals were randomly distributed into 2 groups, with 6 animals each. Abdominal sepsis was induced by cecum ligation and puncture (CLP) in both groups. Group 1 was subjected to peritoneal lavage three times with $5 \mathrm{ml}$ of saline each time; Group 2 submitted to peritoneal lavage with $5 \mathrm{ml}$ of coconut water also three times. Peritoneal lavage occurred 24 hours after CLP. Twenty four hours after, liquid from peritoneal cavity was harvested for counting of bacterial colony forming units $(\mathrm{CFU} / \mathrm{mL})$ of both groups. Euthanasia was done with overdose of anesthesia. For 
Peritoneal lavage with coconut water in rats with abdominal sepsis and its effects in peritoneum Borges KMB, et al

histopathological analysis, fragments of the peritoneum were removed, and a score was applied to the degree of inflammation. RESULTS: Group 2 had a lower histopathological score $(p<0.005)$ and the fluid obtained in the first peritoneal lavage showed a lower amount of CFU compared to group 1 ( $p<0.005)$. CONCLUSION: The peritoneal lavage with coconut water positively influenced the inflammatory response in fragments of the peritoneum and the amount of CFU of bacteria in the peritoneal fluid in an experimental model.

KEY WORDS: Peritoneal lavage. Peritonitis Coconut water. Rats.

\section{RESUMO}

Objetivo: O presente estudo tem como objetivo analisar os efeitos da lavagem peritoneal com água de coco na reação peritoneal em modelo de sepse abdominal em ratos. Métodos: Foram utilizados 12 ratos Wistar, machos, pesando entre $310 \pm 15 \mathrm{~g}$. Os animais foram distribuídos randomicamente em 2 grupos, com 6 animais cada. Sepse abdominal foi induzida pela técnica de ligadura e punção do ceco (LPC) em ambos os grupos. Grupo 1 foi submetido à lavagem peritoneal três vezes, com $5 \mathrm{ml}$ de solução salina cada vez; o grupo 2 foi submetido a lavagem peritoneal com $5 \mathrm{ml}$ de água de coco (repetidas três vezes). As lavagens peritoneais ocorreram após 24 horas da LPC. Decorridas 24 horas após a lavagem peritoneal, foi colhido líquido peritoneal para determinação do número de unidades formadoras de colônias (UFC) bacterianas de ambos os grupos. A eutanásia dos ratos foi feita com superdose de anestésico. Para análise histopatológica foram retirados fragmentos do peritônio, sendo aplicado escore para graduação da inflamação. Resultados: o grupo 2 apresentou menor escore histopatológico $(p<0,005)$ e o fluído obtido na primeira lavagem peritoneal evidenciou menor quantidade de UFC comparado ao grupo 1 ( $p<0,005)$. Conclusão: a lavagem peritoneal com água de coco diminuiu a resposta inflamatória em fragmentos do peritônio e a quantidade de UFC de bactérias no fluído peritoneal em um modelo experimental.

Descritores: Lavagem peritoneal. Peritonite. Sepse abdominal. Água de coco. Ratos.

\section{INTRODUCTION}

Peritonitis is an inflammation affecting the peritoneal membrane, which is of great clinical importance because peritonitis is one of the major causes of sepsis and death in operated patients and in intensive care units. It has several etiologies, being 
Peritoneal lavage with coconut water in rats with abdominal sepsis and its effects in peritoneum Borges KMB, et al

classified as acute or chronic, primary, secondary or tertiary, bacterial or non-bacterial ${ }^{1}$. The treatment of the patient presenting such clinical condition includes the administration of antimicrobials, restoration of tissue integrity and peritoneal lavage, which is performed with either isotonic solutions or with antimicrobial or antiseptical solutions. The best solution for this purpose is under the objective of research ${ }^{1,2}$.

The peritoneal lavage helps immune function in combating abdominal sepsis, as it improves cavity cleanliness, facilitates aspiration of contaminants, and reduces the concentration of bacteria and other substances ${ }^{3}$. However, with the increase in bacterial resistance of the microorganisms usually involved in the infection, in view of the intestinal microbiota, new and more effective treatments are sought for its resolution by reducing the use of drugs ${ }^{2,14}$. In the treatment of perforated diverticulitis, one of the main causes of acute secondary bacterial peritonitis, peritoneal lavage is preferred in its treatment; It is usually composed by surgical resection of the affected colon ${ }^{5}$. Currently, the most used alternative is laparoscopic lavage, with adequate drainage and antimicrobial therapy ${ }^{6}$.

In addition to peritoneal lavage, the Surgery for Damage Control (DCS) is one of the surgical options for the treatment of peritonitis. Because of its intense inflammatory response, the DCS treatment aims to restore mean arterial pressure, central venous pressure and heart rate. Jason et.al ${ }^{7}$ demonstrated in their study that intraperitoneal infusion of hyperconcentrated glucose solution improves tissue perfusion, reducing the risk of progressive ischemia and shock triggered by the intense inflammatory response present in peritonitis. Abdominal sepsis mortality increases when systemic and multiple organ dysfunction occurs and is related to several inflammatory cytokines, such as TNF- $\alpha$, IL-1 $\beta$, IL-6, IL-8 and nitric oxide ${ }^{8}$. The aim Jason et al study was to search for another type of liquid used in the peritoneal lavage to reduce the presence of cellular hypoxia, microcirculatory hypoperfusion and inflammation ${ }^{7}$.

Efforts to apply treatments that avoid the prolonged use of antimicrobials in a peritonitis scenario led several researchers to search for different solutions for peritoneal lavage that would minimize the inflammatory effects triggered by pathogens. A study conducted by Brocco et al ${ }^{2}$ evaluated the histological effects on the lung, liver and peritoneum of rats submitted to peritonitis and treated with peritoneal lavage with $0.2 \%$ 
Peritoneal lavage with coconut water in rats with abdominal sepsis and its effects in peritoneum Borges KMB, et al

ropivacaine, an anesthetic with anti-inflammatory and antimicrobial effects. Araújo et al ${ }^{3}$ reported that peritoneal lavage with $10 \%$ povidone-iodine solution reduced bacterial uptake in rats when compared to control and saline lavage groups.

Although several papers discuss various substances and their benefits in peritoneal lavage, there are still controversies about their actual effects. Peritoneal lavage with saline solution has been associated with impairment of peritoneal cell defense. Antimicrobial solutions present several arguments against its application because they do not eliminate bacteria from the cavity, present toxicity, promote uncontrolled absorption of the drug and formation of adhesions. After peritoneal lavage with PVPI saline in rats, an increase in the number of non-phagocytized bacteria in the bloodstream was observed, and it was also associated with tissue toxicity ${ }^{3}$.

In the search for the most suitable liquid, coconut water has several properties that choose it as one of the possible liquids that can be used in the peritoneal lavage. Among them, antioxidant properties related to flavonoids, polyphenols, esters, aldehydes and aromatic compounds were found in the liquid, being of great importance in the treatment of inflammation, besides its composition is rich in electrolytes essential for metabolism, such as glucose, amino acids, potassium, chloride, calcium and magnesium ${ }^{9,10,11}$. Stefan et al. ${ }^{11}$ demonstrated that intravenous infusion of coconut water did not alter homeostasis, stating no change in blood coagulation, and found that the composition of coconut water resembles extracellular fluid more than intracellular fluid. Darilyn C.F. et al. ${ }^{12}$ also reported intravenous infusion of coconut water which, while not the ideal type of resuscitation fluid, may be used in low volume for a short period of time. Coconut water is easily available in Brazil ${ }^{13}$.

Therefore, the objective of this study is to evaluate the effects of peritoneal lavage with coconut water in rats submitted to abdominal sepsis and its effects on peritoneal reaction and bacterial count. 
Peritoneal lavage with coconut water in rats with abdominal sepsis and its effects in peritoneum Borges KMB, et al

\section{METHODS}

This project was approved by the institutional Ethics Committee on Animal Use (Protocol 01/16).

\section{Animals and experimental design}

Male Wistar rats (Rattus norvegicus albinus, Rodentia mammalia) weighing $310 \pm 15 \mathrm{~g}$ were used. Control of humidity, particles and temperature were maintained, with free access to water and food throughout the experiment, without preoperative fasting. Twelve rats were randomly assigned to 2 groups, with six animals each. For anesthesia, ketamine $70 \mathrm{mg} / \mathrm{kg}$ and xylazine $(10 \mathrm{mg} / \mathrm{kg}$ ) were administered intraperitoneally. The experimental design followed the scheme described in the chart below (Figure 1).

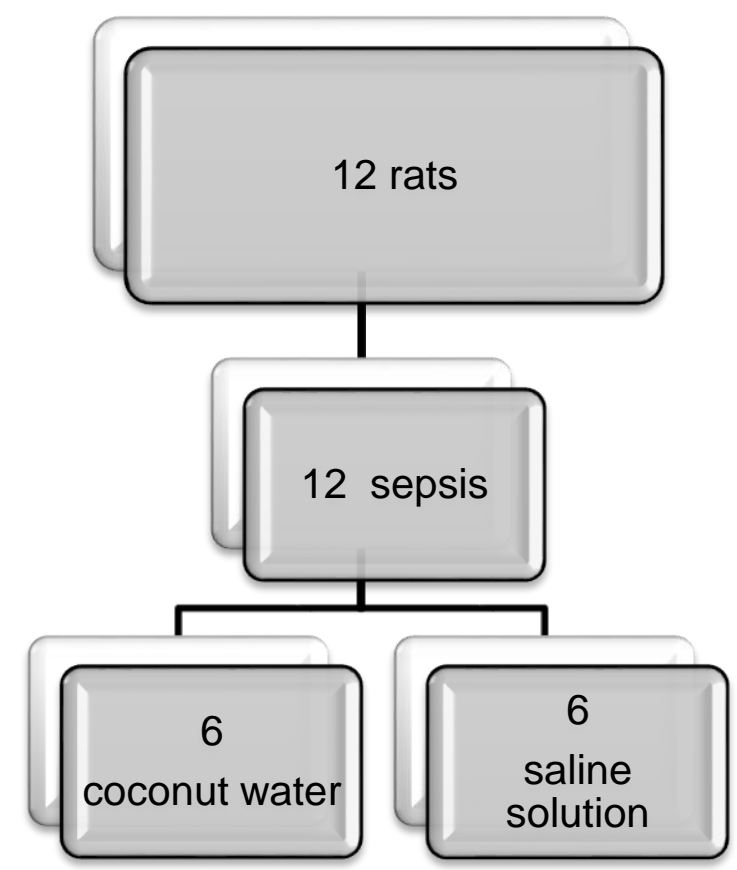

Figure 1 - Experimental design; division of the study groups coconut water and saline solution. 
Peritoneal lavage with coconut water in rats with abdominal sepsis and its effects in peritoneum Borges KMB, et al

\section{Induction of abdominal sepsis}

In all animals abdominal sepsis was induced using cecum ligation and puncture (CLP). After induction of anesthesia with ketamine $70 \mathrm{mg} / \mathrm{kg}$ and xylazine $10 \mathrm{mg} / \mathrm{kg}$ intraperitoneal and depilation of the abdominal wall, a median laparotomy of $3 \mathrm{~cm}$ was performed by using aseptic technique. The cecum was identified, exposed and a ligature with cotton thread No. 00 was preformed $1 \mathrm{~cm}$ distal to the ileocecal junction. Four perforations were done in the distal segment of the cecum with a $25 \mathrm{G}$ sterile needle.

Postoperative analgesia was performed with meperidine $10 \mathrm{mg} / \mathrm{kg}$ s.c. $12 / 12 \mathrm{~h}$.

\section{Coconut water: collection and handling}

Coconut water was obtained from coconut (Cocus nucifera L.) specimens of 6 months (period from inflorescence to fruit harvest), with sterile technique, withdrawn from the coconut immediately prior to administration to the animals. The $\mathrm{pH}$ of the coconut water was determined (Micronal, São Paulo, Brazil), and it was previously adjusted to 7.4 using $20 \%$ sodium bicarbonate, followed by sterile filtering.

The timeline of procedures are summarized in figure 2 .

\section{Timeline}

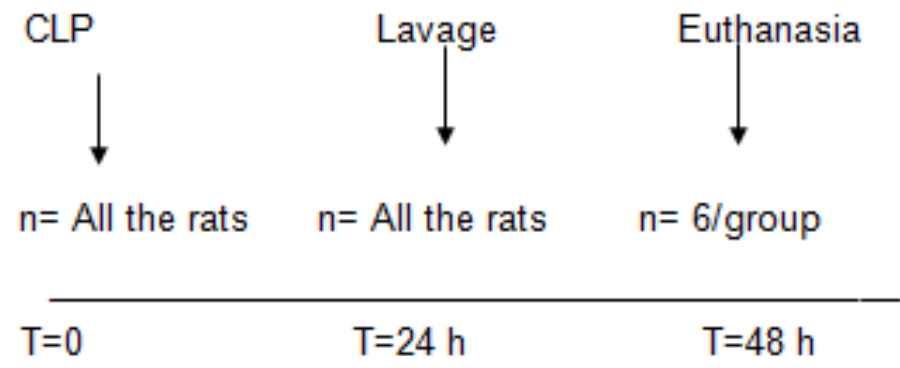

Figure 2 - Timeline. 
Peritoneal lavage with coconut water in rats with abdominal sepsis and its effects in peritoneum Borges KMB, et al

\section{Peritoneal lavage}

Twenty-four hours after the CLP, the rats were reanesthetized for relaparotomy. Peritoneal lavage therapy was repeated 3 times, each wash with $5 \mathrm{ml}$ of solution, which remained in the peritoneal cavity for 1 minute, and then was withdrawn with sterile dry gauze at the end of each lavage. The solutions were heated to $37^{\circ} \mathrm{C}$ just prior to use.

In 6 animals from the sepsis + coconut water group, the abdominal cavity was washed with coconut water; In the remaining 6 animals, washing was done with $0.9 \%$ saline solution. After washing, the abdominal cavity was closed with 2 suture planes (nylon 00) and the animals were placed in individual cages for observation. Volume resuscitation was done with $10 \mathrm{ml}$ of saline solution subcutaneously twice daily. For the histopathological analysis, the observation period was $48 \mathrm{~h}$, counted from the CLP.

\section{Bacteriological study}

The fluid from the first wash was collected for bacteriological study. A calibrated bacteriological loop $(1 \mu \mathrm{l})$ was introduced into the sample. The liquid was distributed on the surface of the culture medium Cromoclin US (Paraná, Brazil) and incubated for $24 \mathrm{~h}$ at 35 으. After bacterial growth, colonies identified by specific colors were counted. The number of colonies was multiplied by the dilution factor of the loop to obtain the number of Colony Forming Units per $\mathrm{ml}$ of sample (CFU/ml). The identification of the bacterial colonies was done by their colors. A Rugai Kit with lysine wasl be used to identify the respective strains. Quantification was done in colony forming units/ml (CFU/ml), transformed in logarithm.

\section{Histopathological evaluation}

Twenty four hours after samples collection for bacterial count, peritoneum biopsies (abdominal wall close to the septic focus) were collected. Euthanasia was performed with anesthetic overdose (thiopental $100 \mathrm{mg} / \mathrm{kg}$ ). Samples were immediately fixed in $10 \%$ buffered formaldehyde and routinely processed for staining with hematoxylin and eosin. Histological slides were examined by an experienced pathologist 
Peritoneal lavage with coconut water in rats with abdominal sepsis and its effects in peritoneum Borges KMB, et al

without prior knowledge of the respective groups. The tissue response was evaluated in scores according to the method used by Storch et al. In this system, tissue samples were examined microscopically taking into consideration the parameters with respective weights: neutrophils (6), macrophages (1), giant cells (2), edema (2), lymphocytes (2), cell density ) and fibroblasts (1), which were quantified on a scale of 1 to 10 , with 10 representing the highest possible concentration of cells. These data were weighted to emphasize the significance of the inflammatory response, attributing the highest value to neutrophils. The sum of the weighted values generated an aggregate score of the tissue response for each animal.

\section{Statistical analysis}

The normality assumption was assessed using the Shapiro Wilk and Kolmogorov-Smirnov test. To test the hypothesis of the difference between the two groups, Student's t-test was used for independent samples, with a significance level of $5 \%$. The statistical package SPSS ${ }^{\circledR} 21$ was used.

\section{RESULTS}

The histopathological scores and the quantification of the bacterial colonies units $/ \mathrm{mL}$ on the group submitted to peritoneal lavage with coconut water were significantly lower than that observed in the saline control group rats $(p<0.001)$. Histopathological analysis of peritoneum fragments in the group submitted to peritoneal lavage with coconut water revealed a lower number of inflammatory cells and fibrin deposits, revealing the superiority of this fluid, comparing with the saline solution. These data are summarized in table 1 . (Figures $3,4,5$ and 6 ). 
Peritoneal lavage with coconut water in rats with abdominal sepsis and its effects in peritoneum Borges KMB, et al

Table 1 - Results of descriptive statistics of the variables and respective inferential statistical test.

\begin{tabular}{lccc}
\multicolumn{1}{c}{ Variables } & Coconut water & Groups & \\
Histopathological & $18,2 \pm 6,05$ & $47,7 \pm 8,43$ & -value \\
$\begin{array}{l}\text { score } \\
\text { Colony forming } \\
\text { units } / \mathrm{mL}(\mathrm{CFU} / \mathrm{mL})\end{array}$ & $16,8 \pm 3,97$ & $82,0 \pm 9,69$ & $<0,001$ \\
\hline
\end{tabular}

Mean \pm standard deviation

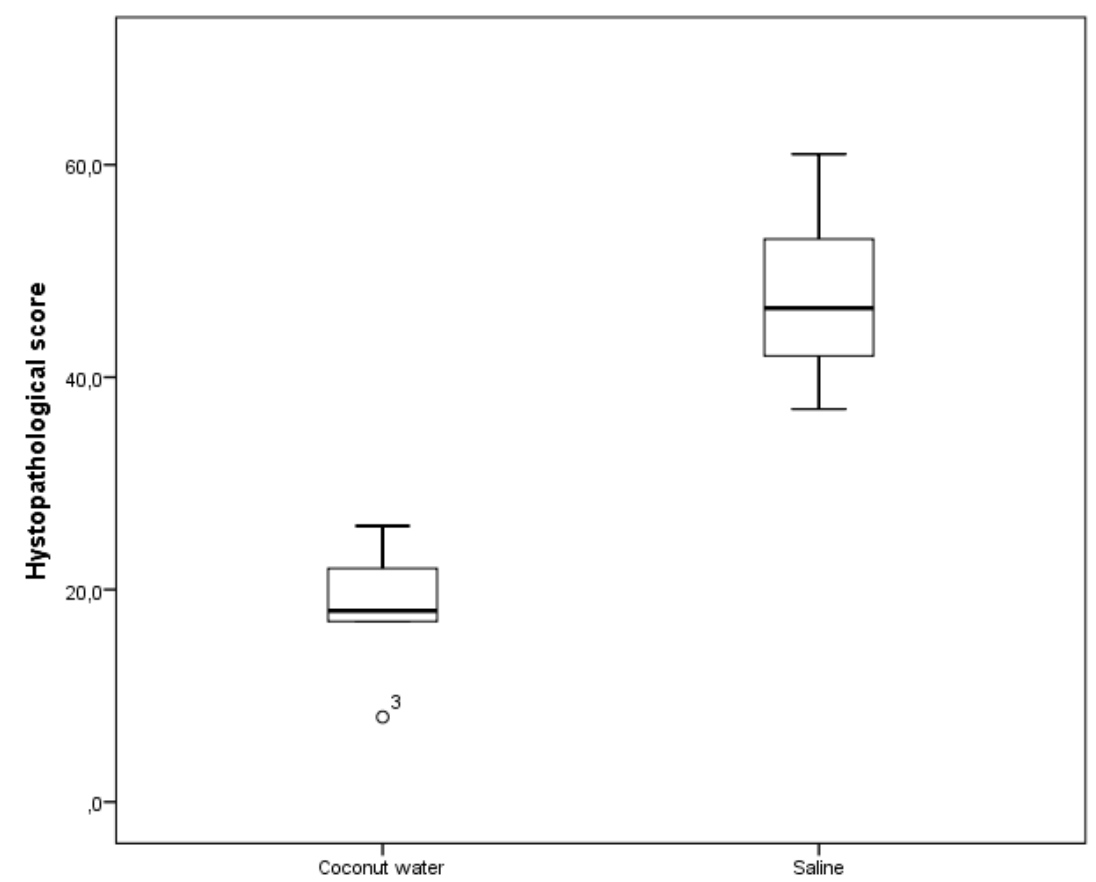

Figure 3 - Box-plot of histopathological scores, comparing group. 


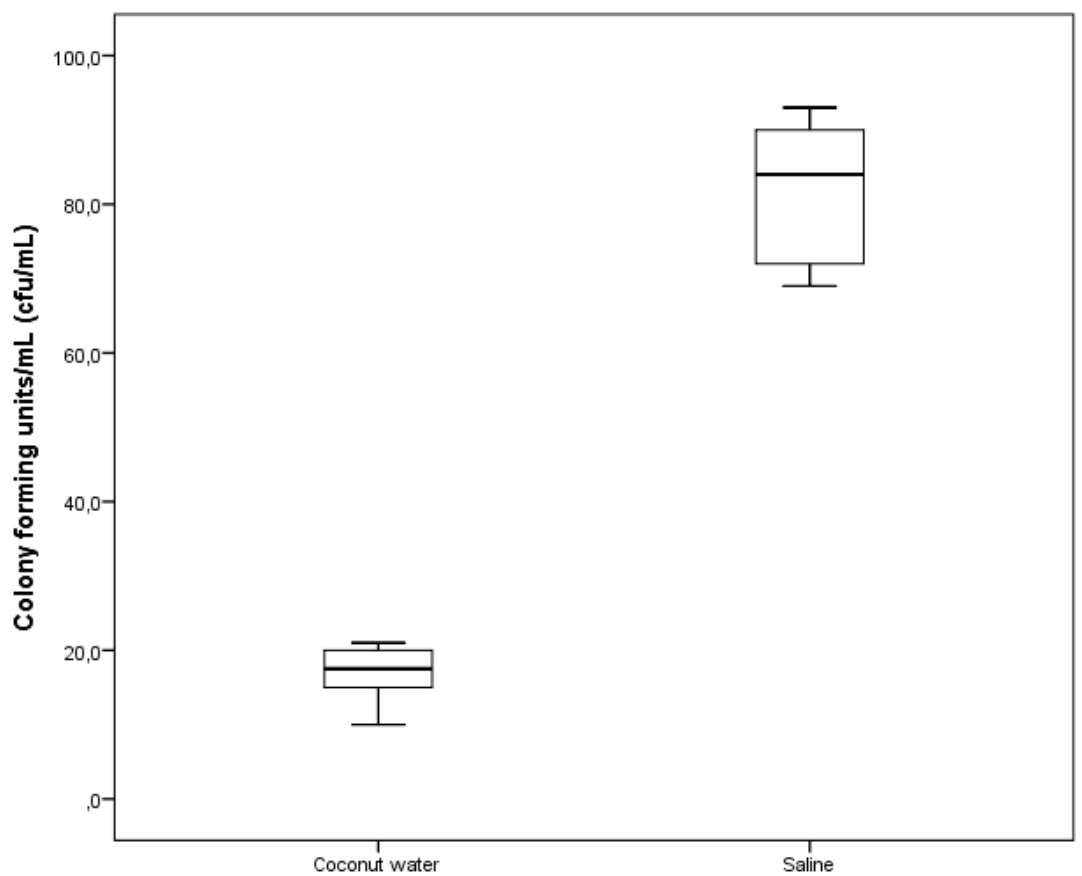

Figure 4 - Box-plot of the variable colony-forming unit/mL (CFU/mL), comparing groups.
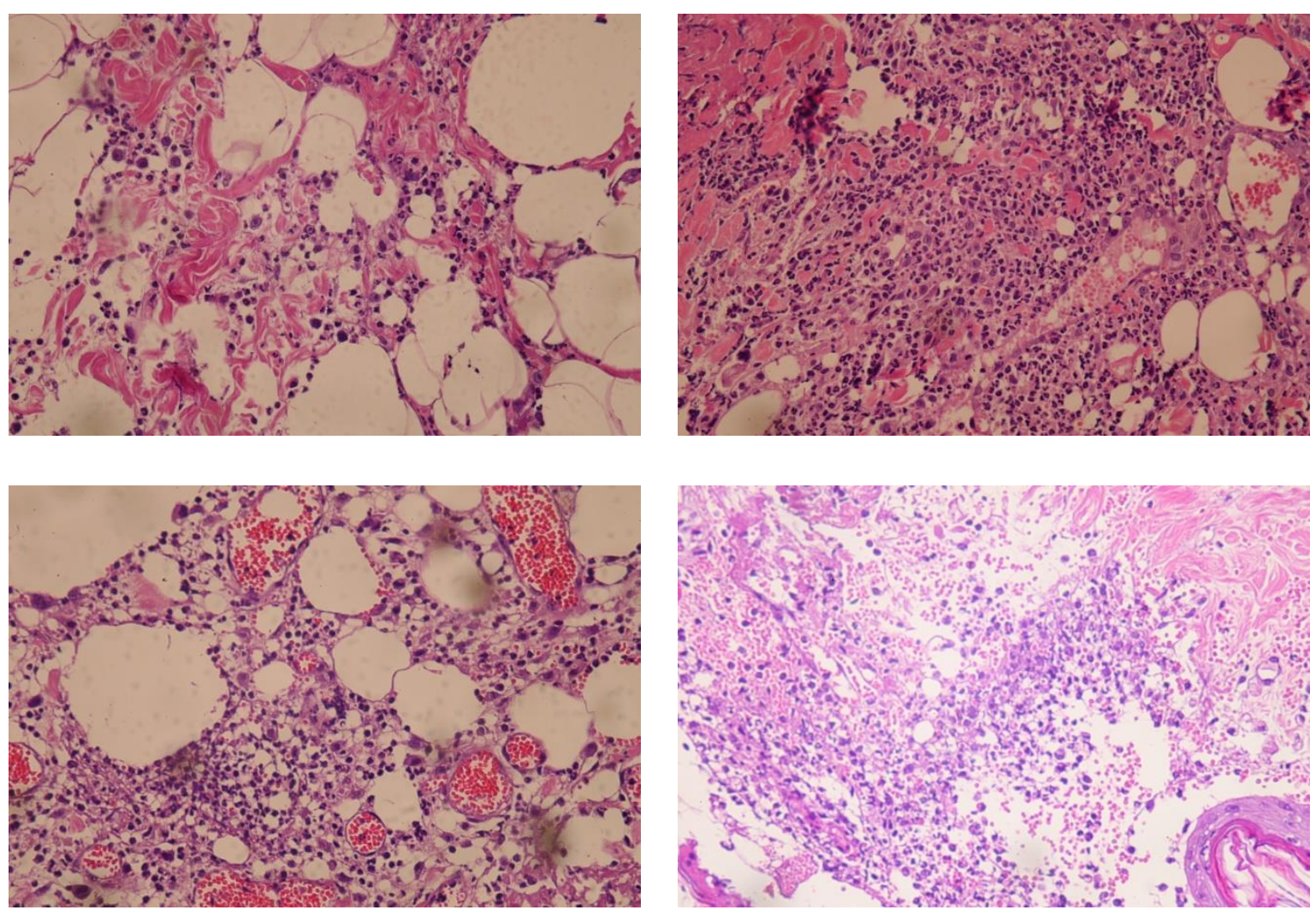

Figure 5 - Sepsis + saline group. Histopathological findings in the peritoneal membrane. $\mathrm{HE}, 100 \mathrm{x}$ 

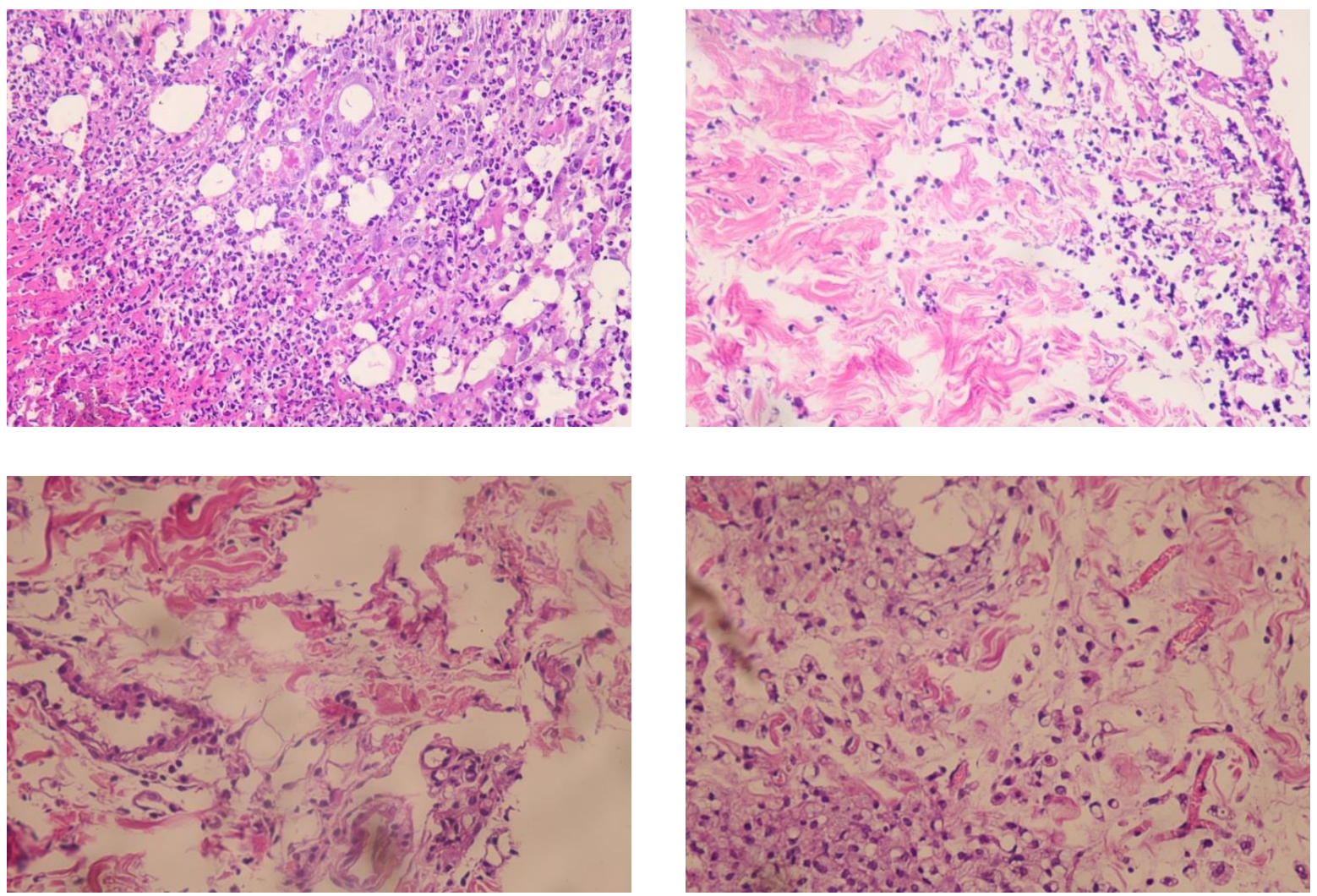

Figure 6 - Sepsis group + coconut water. Histopathological findings in the peritoneal membrane. HE, 100x

\section{DISCUSSION}

Previous studies have discussed the anti-inflammatory, antibacterial, antifungal and antioxidant effects of coconut water ${ }^{9,10,15}$. In our study Its properties resulted in lower amounts of $\mathrm{CFU} / \mathrm{mL}$ and better histopathological score compared to the group submitted to peritoneal lavage with saline solution.

In sepsis, mortality occurs due to the intense inflammatory cascade triggered by the infection, in which it involves inflammatory mediators such as TNF-alpha, IL-1 and IL-6 16,17. KEITH R et al ${ }^{16}$ demonstrated that the severity of sepsis is associated with imbalance between inflammatory cytokines, which in turn have a significant impact on mortality. This inflammatory response can be observed through the histopathological analysis of the peritoneum fragments, being possible to quantify it through the used score. As described in this study, the histopathological findings of the coconut water lavage are consistent with a lower inflammatory response compared to the saline group. 
Peritoneal lavage with coconut water in rats with abdominal sepsis and its effects in peritoneum Borges KMB, et al

Previous analyzes with other solutions for peritoneal lavage were made comparing them to the $0.9 \%$ saline solution. Local anesthetics, such as ropivacaine and lidocaine, were applied as adjuncts to the peritoneal lavage, showing good results ${ }^{2,8}$. Povidiultane-iodine (PVPI) was also compared to lavage with $0.9 \%$ saline solution, which was positive ${ }^{3}$. Among plants, the extract of Aloe vera and Euphorbia tirucalli latex were objects of study in peritoneal lavage in an experimental model ${ }^{18,19}$. However, no studies were found with the fruit water of Cocus nucifera L., although its medicinal properties have already been evaluated $9,11,12,20$. Unlike the other studied solutions, coconut water has easy preparation and low production costs. Brazil is a country with increasing production of coconut water, and has adequate climatic conditions for its development ${ }^{13}$.

Although the effect of peritoneal lavage is not yet a consensus ${ }^{21}$, our study showed superiority of coconut water compared to saline concerning to inflammation and amount of $\mathrm{CFU} / \mathrm{mL}$ in peritoneal membrane. A recent work of our group, studing the treatment of sepsis simultaneously with hemorrhagic shock, concluded that resuscitation with coconut water with $\mathrm{Nacl} 3 \%+$ simvastatin had a significant beneficial effect on downregulating cytokines and decreasing lung injury in a rat model of abdominal sepsis and hemorrhagic shock. It was also demonstrated that coconut water with Nacl $3 \%+$ simvastatin administration clearly made liver and kidney function better and improved clinical score ${ }^{21}$.

\section{CONCLUSION}

The peritoneal lavage with coconut water positively influenced the treatment of abdominal sepsis, when compared with saline in an experimental model.

\section{REFERENCES}

1. Hadley G.P. Intra-abdominal sepsis-Epidemiology, aetiology and management. Semin Pediatr Surg. 2014; 23(6): 357-62.

2. Brocco MC, Gomez RS, Paulo DNS, Almeida CED, Baptista JFA. Histological features of peritoneal lavage with ropivacaine in rats with fecal peritonitis. Acta Cir Bras. 2012; 27(2): 193-9. 
Peritoneal lavage with coconut water in rats with abdominal sepsis and its effects in peritoneum Borges KMB, et al

3. Araujo I D, Grossi G C X, Diniz S O F, Nunes T A, Braga E A, Cardoso V N. Effects of the povidone-iodine (PVPI) in treatment os bacterial peritonitis induced in rats. Acta Cir Bras. 2010; 24(4): 322-7.

4. Sawyer RG, Claridge JA, Nathens AB, Rotstein OD, Duane TM, Evans HL, et al. Trial of Short-Course Antimicrobial Therapy for Intraabdominal Infection. N Engl J Med. 2015; 327 (21):1996-2005.

5. Radé F, Bretagnol F, Auguste M, Di Guisto C, Huten N, de Calan L. Determinants of outcome following laparoscopic peritoneal lavage for perforated diverticulitis. Br J Surg. 2014; 101(12):1602-6.

6. Toorenvliet BR, Swank H, Schoones JW, Hamming JF, Bemelman W. Laparoscopic peritoneal lavage for perforated colonic diverticulitis: systematic review. Color Dis. 2010; 12(9): 862-7.

7. Smith JW, Neal GR, Matheson PJ, Harbrecht BG, Benns M V, Franklin G, et al Adjunctive treatment of abdominal catastrophes and sepsis with direct peritoneal resuscitation: indications for use in acute care surgery. J Trauma Acute Care Surg. 2014; 77(3): 393-8.

8. Brocco MC, Paulo D N S, Baptista J F A, Ferrari T A, Azevedo T C V, Silva A L. Effects os peritoneal lavage with lidocaine on survival of rats with fecal peritonitis. Acta Cir Bras. $2008 ; 23(1): 42-7$.

9. Fonseca AM, Ayla MCB, Souza JSN, Monte FJQ, Oliveira M C F, Mattos M C M. Constituents and antioxidant activity of two varieties of coconut water (Cocos nucifera L.). Rev Bras de Farmacog. 2009; 19(1B): 193-8.

10. Silva DV, Alves RE, Figueiredo RW, Maciel VT, Farias JM, Aquino A.R.L. Características físicas, físico-químicas, e sensoriais da água de coco de frutos do coqueiro anão verde oriundo de produção convencional e orgânica. Ciênc Agrotec Lavras. 2009; 33(4): 107984.

11. Pummer S, Heil P, Maleck W, Petroianu G. Influence of coconut water on hemostasis. Am J Emerg .Med. 2001; 19(4): 287-9.

12. Falck DC, Thomas T, Falck TM, Tutuo N, Clem K. The intravenous use of coconut water. Am J Emerg Med. 2000; 18(1): 108-11.

13. Neto M F, Gheyi H R, Holanda J S, Medeiros J F, Fernandes P. D. Qualidade do fruto verde de coqueiro em função da irrigação com água salina. Rev Bras Eng Agrí Amb. 2002; 6(1): 69-75.

14. Storch M, Perry LC, Davidson JM, Ward JJ. A 28-day study of the effect of Coated VICRYL* Plus Antibacterial Suture (coated polyglactin 910 suture with triclosan) on wound 
Peritoneal lavage with coconut water in rats with abdominal sepsis and its effects in peritoneum Borges KMB, et al

healing in guinea pig linear incisional skin wounds. Surg Infect (Larchmt). 2002;3 Suppl 1: S89-98.

15. Lima EBC, Sousa CNS, Meneses LN, Ximenes NC, Júnior MAS, Vasconcelos GS, et al. Cocos nucifera (L.) (Arecaceae): A phytochemical and pharmacological review. Braz J Med Biol Res. 2015; 48(11): 953-64.

16. Walley KR, Lukacs NW, Standiford TJ, Strieter RM, Kunkel SI. Balance of inflammatory cytokines related to severity and mortality of murine sepsis. Infect immun. 1996; 64(1): 4733-8.

17. Iskander KN, Osuchowski MF, Stearns-Kurosawa DJ, Kurosawa S, Stepien D, Valentine C, Remick DG. Sepsis: multiple abnormalities, heterogeneous responses, and evolving understanding. Physiol Rev. 2013; 93: 1247-88.

18. Altincik A, Sönmez F, Yenisey Ç, Duman S, Can A, Akev N, Kirdar S, Sezak M. Effects of Aloe vera leaf gel extract on rat peritonitis model. Indian J Pharmacol. 2014; 46(3): 322-7.

19. Araújo LA, Mrué F, Neves RA, Alves MM, Júnior NJS, MS, Silva MSB, Reis PRM. Effects of topical treatment with Euphorbia tirucalli latex on the survival and intestinal adhesions in rats with experimental peritonitis. Arq Bras Cir Dig. 2015;28(4):243-246.

20. Alleyne T, Roache S, Thomas C, Shirley A. The Control of Hypertension by use of Coconut Water and Mauby: Two Tropical Food Drinks. West Indian Med J. 2005; 54(1):38.

21. Whiteside OJ, Tytherleigh MG, Thrush S, Farouk R, Galland RB. Intra-operative peritoneal lavage - who does it and why? Ann R Coll Surg Engl. 2005; 87: 225-8.

22. Medeiros VF, Azevedo ÍM, Carvalho MD, Egito ES, Medeiros AC. Effects of cococonut water and simvastatin in the treatment of sepsis and hemorrhagic shock in rats. Acta Cir Bras. 2016;31(12):826-33. 